\title{
AS METÁFORAS NA HISTÓRIA
}

\section{The Metaphors in History}

Diogo da Silva Roiz

FONTANA, Josep. A Europa diante do espelho. Tradução de Omar Ribeiro Tomaz. São Paulo: EDUSC, 2005, 194 p.

De acordo com a interpretação cética, dita pós-moderna, os historiadores sempre teriam se utilizado de metáforas para darem sentido ao seu discurso sobre as sociedades do passado. Esse argumento, reiterado várias vezes por Hayden White, a partir dos anos 1960, foi também a base de severas críticas a respeito da possibilidade de constituição do conhecimento histórico (em moldes "científicos"). Mesmo se utilizando de um denso "artefato verbal em prosa", diz White, os historiadores não reconstituiriam a História na sua totalidade. E, conforme argumenta Paul Veyne, eles apenas atingiriam fragmentos, pequenas frações de um passado remoto, com os quais procuram dar um sentido para escreverem "histórias" de um ou outro ponto do passado. Não por acaso, White completaria essa argumentação dizendo: de um passado apenas retrospectivamente elaborado, de acordo com certas "urdiduras de enredo", com as quais os historiadores lhe dariam um sentido prévio. Antes deles, Roland Barthes já havia dado ênfase à forma como os historiadores empregavam certas metáforas na construção de suas narrativas, com o célebre exemplo de Jules Michelet. Os historiadores estariam, nesse sentido, elaborando o seu espaço com base em práticas discursivas que almejariam o poder, de modo a restringir críticas que viessem a demonstrar as fissuras de sua narrativa histórica, de um lado por não ser científica e, de outro, por não ser poética, mas que autores como Roland Barthes, Hayden White, Michel Foucault, Paul Veyne, dentre outros, vieram-lhes indicar. Nesse caso, e de acordo com esses autores, todas as

\footnotetext{
"Doutorando/UFPR.
} 
escolas historiográficas "pecaram" por imporem alternativas aos problemas de suas épocas, com o inadequado argumento de que iriam lhe definir um passado, e relações de proximidades e distanciamentos, quando na verdade os historiadores não têm como atingir nem as sutilezas, nem o realismo do que passou. White diz ainda sobre isso que não haveria diferenças entre as narrativas históricas e as narrativas literárias, além de pequenos desvios estilísticos. De modo que perguntas como: o que fazem os historiadores? Para que serve a história que escrevem? Que função têm para a sociedade?, são talvez mais cruciais nesses últimos decênios do que o foram no século XIX.

Durante esse período os historiadores não ficaram em silêncio e muitas respostas foram dadas àqueles argumentos, acima rapidamente resumidos, como o fizeram Arnaldo Momigliano, na Itália, Moses Finley, Eric Hobsbawm e E. P. Thompson, na Inglaterra, nos anos 1960 e 1970, e, mais recentemente, Peter Gay, Jörn Rüsen, Perry Anderson, Peter Burke, Carlo Ginzburg e Robert Darnton. Não cabe aqui reproduzir na íntegra as circunstâncias e os argumentos das respostas. De forma muito resumida: a) White acaba criando um "novo positivismo", o da verdade do texto, e que, além disso, ainda é visto a partir de uma hierarquia de "urdiduras de enredo"; b) dá-se ênfase apenas ao produto final, sem com isso se verificar as diferentes etapas de elaboração do texto histórico (bem como do literário), que está intimamente relacionado ao processo de pesquisa das fontes e a sua interpretação; c) indica-se a "visão de mundo" criada no texto pelo historiador, despercebendo-se que foi produzido a partir de - e com base em - uma realidade extratextual; d) destaca-se a forma, a linguagem, a eficácia e o convencimento retóricos, deixando-se de lado os agentes (os testemunhos), os resquícios, os indícios e as provas; e) presume-se que o texto é um deleite de profissionais, sem com isso constatar as circunstâncias e os problemas que possibilitaram a sua elaboração; f) relativiza-se o discurso, as interpretações e a verdade, quando, de fato, deve-se dar maior atenção à pesquisa, à análise das fontes e à precisão da narrativa.

De modo que, postados nos dilemas resumidamente apontados acima, parece se tornar crucial para o historiador, de tempos em tempos, justificar o seu ofício e definir a sua função na sociedade. De Heródoto a Tucídides, de Lorenzo Valla a Leopoldo von Ranke, de Lucien Febvre e Marc Bloch até Fernand Braudel, e destes ao presente, o ofício de historiador, ao mesmo tempo em que ganhava um caráter cada vez mais profissionalizado, 
também foi indicando a complexidade que era e é escrever a História. A começar pela própria complexidade do termo "História", que, em muitos países, refere-se tanto "ao vivido", "ao acontecido", quanto à(s) "sua(s) interpretação(ões)".

O historiador espanhol Josep Fontana, no decorrer de sua trajetória, se viu sempre instado por esses dilemas, os quais procurou enfrentar ao demonstrar a importância do trabalho dos historiadores quando escrevem suas histórias. Ao mesmo tempo em que justificava seu embasamento teórico e metodológico no marxismo, referia-se constantemente à importância das escolhas políticas dos indivíduos. Nesse sentido, o seu novo livro traduzido no Brasil, A Europa diante do espelho (2005), dá continuidade ou prepara o terreno para as reflexões desenvolvidas em seus livros: História: análise do passado e projeto social (1998), Introdução ao estudo da História Geral (2000), História depois do fim da história (1998) e A história dos homens (2004).

Já em A História dos homens, que foi a reformulação e total ampliação de História: análise do passado e projeto social (publicado nos anos 1970), em função das demandas e características de um "novo" contexto, ele indicava a importância de se pensar a história de todos os homens e mulheres do planeta. Além disso, discordava veementemente dos argumentos "céticos" e "narrativistas", pois:

Os argumentos de White, como o de todos os que pretendem desqualificar a história, reduzindo-a à narração, são irrelevantes. É evidente que a complexidade da tarefa do historiador, enfrentando a diversidade inalcançável do mundo real, obriga-o a fazer seleções - ninguém pode fazer a história "completa", no sentido que exige White, do que aconteceu numa só cidade num só dia do passado - e isso condiciona a perspectiva. Mas estas limitações são um reflexo das vividas pelo homem comum na vida cotidiana. Também ele escolhe os aspectos da realidade que o envolve, considerados de acordo com as necessidades da vida. Também a memória do passado é seletiva e influenciada por preferências diversas, incluindo as políticas, que filtram a percepção do que acontece ao redor. Ao receber as notícias dos acontecimentos imediatos que podem ser importantes para ele, o mais provável é que escolha a fonte de informação de acordo com suas preferências e é certo que nela selecionará 
notícias determinadas. [...] A vida real é assim, não somente a história. Este é o contraste que se estabelece entre o trabalho do historiador e o do teórico de disciplinas culturais que funcionam fabricando pequenos universos delimitados que podem ser manejados com ferramentas elementares. Com isto, o teórico pode alcançar êxito na carreira acadêmica, mas suas ferramentas não servem para nada quando tiver de sair do recinto universitário e enfrentar a realidade exterior, que é matizada e confusa como o panorama do passado em que o historiador se move, guiando-se pelo sentido da utilidade social do trabalho, que é um critério essencial para suas escolhas (2004, p. 402).

Em A Europa diante do espelho, que foi escrito quando corrigia o texto dos anos 1970, que daria base ao seu livro $A$ história dos homens, volta-se mais à reflexão do processo histórico do que à forma como é escrita a História. O texto foi originalmente publicado em 1994, como um dos volumes da coleção A construção da Europa, coordenada por Jacques Le Goff. Traduzido em 2005 para o português, pela editora da Universidade do Sagrado Coração (a EDUSC), o livro permaneceu dividido em dez capítulos, nos quais o autor se debruçou sobre o que definiu como os diferentes espelhos pelos quais perpassou a história europeia. Ao passar em revista a forma como a história europeia havia sido escrita - segundo ele, na maioria das vezes sob um viés tradicional, no qual o uso de metáforas serviu de base para melhor definir as diferentes maneiras com as quais a história havia sido abordada - a saber: o espelho bárbaro, o cristão, o feudal, o do diabo, o rústico, o cortês, o selvagem, o do progresso e o do povo -, vale-se de uma argumentação sofisticada para ressaltar a forma como em diferentes momentos ocorreu, mesmo que em muitos deles de modo sutil e indireto, a imposição de uma escrita da história que dá ênfase à ação de certas camadas, ao mesmo tempo em que a isenta das "injustiças", da "dominação" e das "explorações" que cometeu diante das massas "anônimas", das quais só agora a história tem sido escrita. Cada um desses espelhos demonstra como, em diferentes momentos, sob variadas alegorias, foi sendo construída a identidade europeia.

De imediato, cabe notar que tais espelhos são metáforas que representam uma realidade que é apresentada desfocadamente para conduzir a vontade das massas segundo as orientações de grupos no poder, paralelo ao 
que as ideologias efetuam sobre as "visões de mundo" e a maneira pela qual são impostas. Cada um deles, embora pareçam ser substituídos no tempo de maneira linear, em certas ocasiões coexistem num mesmo espaço e tempo. A ideia que se fazia do bárbaro, por exemplo, em comparação com o cidadão grego ou romano, servia no passado mais para contornar problemas de ordem política e social, porque é mais fácil indicar que as causas de um problema são externas do que internas. Mas a ideia do bárbaro no período contemporâneo teve usos também diversos, porque está intimamente articulada a uma contraposição com o civilizado - estratégia da qual, aliás, os europeus se serviriam para justificar seus projetos de dominação diante dos povos nativos do Novo Mundo. E que igualmente seria articulado junto com o ideário cristão. Desse modo, se há uma sucessão de espelhos no tempo, também existem uma coexistência e até usos diferenciados de uma ou mais dessas metáforas ao mesmo tempo, para justificar determinados tipos de ação. Isso porque, como nos informa, ao se sucederem no tempo, esses espelhos permitem aos grupos no poder se apropriarem de experiências do passado para realçarem, dinamizarem e melhorarem seus sistemas de dominação das massas.

Do mesmo modo, permitiriam definir que tipo de passado deve ou não ser rememorado, como nos informa a respeito do espelho feudal, no qual o "preconceito eurocentrista, que reduz a ciência islâmica a uma mera 'tradução' da velha ciência grega, esquece que a cultura helenística era originariamente algo mestiço, que fundia elementos gregos e orientais, e que os árabes participavam nela desde muito antes" (2005, p. 47). Ou de que a ideia do Diabo, além de figurar como o mal, em oposição ao bem representado por Deus, também servia para designar, em alguns casos, a figura monstruosa do "outro", na qual o "espírito da cruzada deformou não somente nossa percepção do islã, mas também da cristandade oriental e nos levou a excluir Bizâncio da história da Europa", além de excluirmos "também a Rússia, nascida da assombrosa fusão de escandinavos, eslavos e mongóis e, sobretudo, o cristianismo 'asiático"' (p. 58). Nesse aspecto, o judeu também apareceria de maneira deformante, muito embora "não se necessitava de tanto para provar a culpa de alguns judeus que eram percebidos [...] de acordo com a imagem diabólica que refletia o novo espelho deformante" (p. 71).

Além de servirem para justificar projetos de dominação e forjar certos usos do passado, tais espelhos também poderiam fornecer exemplos do passado para auxiliar na orientação das ações no presente. No século XVI, 
por exemplo, quando esteve no auge o que definiu como espelho rústico, "a imagem do inimigo a ser combatido era agora a do 'rústico', que agrega todos os matizes da barbárie, ignorância e baixeza que caracterizam o 'vilão' frente ao "nobre"" (p. 88). No caso da imagem que se fez do "selvagem" no Novo Mundo, o "racismo continuou instalado em nossas sociedades, apesar de que a investigação científica lhe arrebatou qualquer pretensão de legitimidade", dado que não "importa que tenha ou não fundamento, porque não se baseia em ideias raciocinadas, mas em temores inconfessados", pois, não "é mais do que o rosto que toma o medo irracional ao "outro"” (p. 117). Por sua vez, a "história da revolução agrícola costuma ser contada de modo que faz aparecer a destruição das formas comunais de cultivo como uma condição necessária" (p. 138), para o progresso de toda sociedade, quando muitas vezes o que ocorre é justamente o inverso. Foi seguindo esse tipo de modelo que, para "justificar sua superioridade, os europeus especularam acerca do 'milagre' de sua história e das razões - isto é, dos méritos - que podiam explicá-lo", e a primeira "das causas aduzidas é a que associa seu sucesso às qualidades de uma 'raça' de homens superiores" (p. 147). Para ele:

Não basta condenar estes fatos pelo que eles têm de injustiça, reclamando igualdade de tratamento para os excluídos. Essa será uma tarefa inútil, se ao mesmo tempo não se desmontar a trama das ideias que justifica a exclusão. Uma trama da qual é peça essencial essa visão da história que legitima a superioridade dos europeus em nome de seu papel como artífices de um progresso universal, e que pretende converter-nos a todos em cúmplices "natos" de todos os seus abusos, sobre a base de nos ocultar que este suposto progresso se fez às custas, também, da maior parte dos próprios europeus. Porque não se trata somente de que esta visão "eurocêntrica" prive os povos não europeus de sua história (o que é verdade). Seu objetivo mais importante é seguramente arrebatá-la de grandes camadas da própria população europeia, ocultando destas que existem outros passados além daqueles que se canonizou na "história oficial", e que neles podemos encontrar um caudal de esperanças e possibilidades não realizadas, e que muito do que se apresentou como progresso não é mais do que disfarces para formas diversas de apropriação econômica e controle social. Ao retirar das classes populares sua história e sua consciência, reduzimo-las ao papel de selvagens internos (p. 144-5). 
Nesse sentido, o último capítulo, intitulado "Fora da galeria dos espelhos", faz uma avaliação sobre as consequências produzidas na História e na(s) sua(s) escritura(s), em função dos usos decorrentes daquelas estratégias. De acordo com ele:

\begin{abstract}
A primeira coisa que precisamos saber é que nossos problemas e os do mundo subdesenvolvido devem ser solucionados conjuntamente. Se nos empenharmos em nos fechar atrás dos muros, pereceremos nas mãos dos assaltantes de dentro e de fora. Os europeus e sua civilização desapareceriam então, como desapareceram todas as comunidades que perderam sua capacidade de adaptar-se a um entorno mutante. Se isto acontecer, terá se concluído um capítulo da história do homem e outro começará (p. 154).
\end{abstract}

E a posição dos historiadores no enfrentamento dessas questões é um ponto crucial para se "sair da galeria de espelhos deformantes em que nossa cultura está presa”, pois, com isso, "poderemos começar a estudar as sociedades humanas [...] e empreender a tarefa de demonstrar essa visão linear do curso da história que interpreta mecanicamente cada mudança como uma melhora, cada nova etapa como um progresso". Caso contrário:

Os historiadores ler[ão] estas e outras advertências semelhantes [...] sem querer perceber os problemas de fundo que delineavam. E quando o presente veio confirmá-las e jogou por terra seus artifícios interpretativos, abandonaram o enfrentamento com a realidade e se dedicaram a fazer discursos sobre o discurso, porque é mais cômodo ocupar-se das palavras do que dos homens (p. 152).

Esse livro, portanto, tal como seus textos anteriores e posteriores a ele, é um convite à reflexão e ao engajamento dos historiadores nas questões de seu tempo. Pode-se, evidentemente, argumentar que em certas ocasiões o autor é tão severo em suas críticas que nem os historiadores de ofício (extremamente engajados com as discussões dos problemas de sua época) conseguem escapar. Pode-se ainda indicar que por ser um historiador marxista muito "fiel" aos seus ideais, em alguns momentos se atribui mais o 
papel de "juiz" do processo do que de intérprete - que seria mais adequado ao historiador. No entanto, é necessário reconhecer que hoje há poucos historiadores em nosso meio que têm a coragem e a determinação de Josep Fontana de enfrentar diretamente esses dilemas. Em todas as suas obras, há sempre a preocupação com a totalidade do processo histórico, com a história de todos e com o enfrentamento e a demonstração das desigualdades e dos dogmatismos teóricos e metodológicos. Com esse livro, o autor evidencia que o uso adequado de metáforas, articulado com uma interpretação bem fundamentada do processo histórico e das fontes documentais, permite que o historiador construa uma bela narrativa sem que, com isso, deixe de lado a "realidade extratextual" que lhe deu origem e ainda demonstre aos "céticos" pós-modernos que nem tudo é só "discurso".

\section{Referências}

FONTANA, J. [1978] História: análise do passado e projeto social. Bauru: EDUSC, 1998. . [1992] História depois do fim da história. Bauru: EDUSC, 1998. . [1997] Introdução ao estudo da História Geral. Bauru: EDUSC, 2000. . [2000] A história dos homens. Bauru: EDUSC, 2004. . [1994] A Europa diante do espelho. Bauru: EDUSC, 2005.

Recebido em junho de 2011. Aprovado em agosto de 2011. 